\title{
Populismen i Europa - en risikovurdering
}

Af Peter Wivel

Europas populistiske partier kan, alt efter politisk ståsted, blive en trussel mod vores demokratier, imod vores velstand og, sidst men ikke mindst, imod vores sikkerhed i en større global forstand. De kan omvendt også betragtes som åbninger, der styrker demokratiet ved at give ordet til grupper, der savner representation, og som nu tilbyder eller beder om uortodokse løsninger på problemer, der ikke er blevet opfanget af parlamentarismens ellers fintmaskede net. Derfor er en risikovurdering altid på sin plads.

Hvad enten populisme er farlig eller nyttig eller begge dele, gør to markante eksempler, det britiske nej til EU og den republikanske præsidentkandidat Donald Trumps letfærdige udtalelser om NATOs forpligtelser, det i alt fald tydeligt, at national populisme kan få vidtrækkende internationale følger, og at disse følger i høj grad også kan ramme de lande selv, hvor populismen sætter sig mest kompromisløst igennem.

Et britisk vælgerflertals nej i juni til fortsat britisk medlemskab af den Europæiske Union har allerede sat spørgsmålstegn ved EU's fremtid, ja endog fællesskabets eksi- stens. Afstemningsresultatet var en følge af årtiers populistisk kampagne imod EU, anført af personer, der meget langt fra tilhører sultens slavehær. Afstemningen har markant øget centrifugalkræfterne i Europa.

Kort efter denne historiske skilsmisse såede Trump i sin tale til det Republikanske Konvent $\mathrm{i}$ juli tvivl om den såkaldte 'musketéred' i NATO. Og det var historisk. Alliancens artikel 5 bestemmer kollektivt forsvar sådan, at et angreb på én af parterne i NATO må anses for et angreb på alle parter. Trump skabte usikkerhed omkring de baltiske lande på et tidspunkt, da den russiske præsident Vladimir Putin formelt undersøger lovmedholdeligheden af den selvstændighed, som disse lande opnåede i 1991 - mens han reelt rasler med sværdet.

Tænketanken Eurasia Group, en af verdens førende rådgivere i politiske risiko-scenarier, skrev i januar, at dens risikoanalyse identificerede to hovedtrusler mod verdens stabilitet i 2016: På førstepladsen ligger det atlantiske samarbejde, 'den hule alliance', skarpt forfulgt af det, rapporten kalder 'det lukkede Europa. Eurasia Group spår, at europæerne og amerikanerne i stigende grad vil slippe

Peter Wivel er tidligere chefredaktør for Information, Weekendavisen og Berlingske Tidende. Han har siden 2004 skrevet for Politiken fra Berlin. 
Eurasia Group advarer ikke mod et sammenbrud i eurozonen, men mod "populismens og nationalismens vækst, undermineringen af retssamfundet og truslen mod den samlede Schengen-aftale om åbne grænser.

taget i hinanden. Den splittelse truer verdenshandelen og den globale sikkerhed.

"Der er bare ikke længere nogen som helst international brandmand: Dette år vil opleve både en tøvende verdensleder og en svagere vestlig koalition. Hvis man tror, at Mellemøsten gav problemer i 2015, så velkommen til 2016", hedder det i prognosen, der mildt sagt ikke er gjort til skamme.

\section{Angreb på fællesskabets ide}

Eurasia Group advarer ikke mod et sammenbrud i eurozonen, men mod "populismens og nationalismens vækst, undermineringen af retssamfundet og truslen mod den samlede Schengen-aftale om åbne grænser. Risikoen begynder i toppen".

"Et helt og frit Europa er det største demokratiske eksperiment, der nogensinde er taget initiativ til. Det handler om at bygge åbne samfund og forankre fælles værdier i lov for at undgå krig. Europas økonomi vil ikke bryde sammen i 2016. Dets dybere mening og dets sociale grundlag vil", skriver den amerikanske tænketank. Nu ser vi, at det netop er fællesskabets idé og sociale grundlag, populisterne anfægter.

De to eksempler skal ikke få os til at glemme, at traditionel politik inden for de etablerede demokratiske værdisystemer både kan og har forårsaget selvforskyldte katastrofer. Men i en situation hvor populistiske partier i Europa har vundet en større parlamentarisk indflydelse end nogensinde siden mellemkrigstiden, hviler ansvarets byrde også på deres skuldre.

Men hvad taler vi om? Den tyske samfundsforsker Jan Werner Müller forstår ved populisme (Was ist Populismus, 2016) en ganske bestemt forestilling om politik, hvor et moralsk rent og homogent folk altid står over for en umoralsk og korrupt elite, der fornægter sit folk og udsuger det. Folkeviljen er per definition moralsk ren. I populistisk ideologi kan folket ikke være korrumperet, selv om det måske nok kan være forført.

Den nu afdøde argentinske teoretiker Ernesto Laclau, der inspirerer venstrepopulistiske bevægelser i Europa og Latinamerika med sit hovedværk om populisme (On Populist Reason, 2005), hæfter sig på den anden side ved, at den videnskabelige litteratur om begrebet har overraskende svært ved at give en sammenhængende beskrivelse af et massefænomen, der hverken er højre eller venstre, hverken by eller land, både jordnært og autoritetstro, både egalitært og eksklusivt, både instinktivt og kontant. For forskningen er populisme et syndrom, mener Laclau.

Laclau mistænker etablerede forskere for at anskue folkelig populisme gennem klassefordomme eller psykologisering. Populister er anti-intellektuelle, antielitære og anti-rationelle. Netop derfor skal forskere vogte sig for at analysere populistiske bevægelser gennem alt for intellektuelle, alt for elitære og alt for rationelle briller. Så ser de ikke, at der kan være mening i galskaben.

Laclau spørger: "Er den etablerede kritik af populisme i virkeligheden et forsøg på at konstruere en politisk normalitet, der ikke anerkender en anden logik end sin egen? Er populisme farlig, fordi demokrati er farligt?"

Den svenske forsker Andreas Johansson 
Heinö gjorde i juni 2016 status over den 'autoritære populismes' fremgang ved nationale valg siden 1980 i samtlige EUlande og Island, Norge, Schweiz, Serbien og Montenegro (Timbro Authoritarian Populism Index 2016).

\section{Populistisk bølge}

Konklusionen lyder, at populistiske partier aldrig har haft stærkere støtte i europæiske demokratier end nu. Hver femte vælger i Europa stemmer populistisk. Populistiske partier sidder i regeringer i ni europæiske lande (bl.a. i Norge og Finland) og støtter regeringer i yderligere to (bl.a. i Danmark). Hver tredje europæisk regering er sammensat eller støttes af autoritære populister. Den langt overvejende del af højre- og venstrepopulistiske partier planlægger ikke indførelse af et diktatur. Ved demokratiske valg i Europa har totalitære partier ingen succes.

Heinös tal overdriver ikke. Valgsystemerne i store lande som Frankrig og Storbritannien er ekstremt diskriminerende over for mindre partier, herunder de populistiske.

Nigel Farage og Marine Le Pen savner stort set al repræsentation, selv om de to populisters partier samlet fik mere end 10 millioner stemmer ved de nationale valg i henholdsvis Storbritannien i 2015 og Frankrig 2012. Populisternes samlede styrke i Europa er altså langt større, end Heinös statistik fortæller.

"Det er svært at overvurdere betydningen af denne udfordring til de politiske eliter", skriver Heinö. Den vigtigste iagttagelse i hans analyse er imidlertid, at populisme ikke skyldes tilfældige luner og ikke ene og alene kan forklares med, at populistiske vælgere er globaliseringstabere, ofre for monumental global og national ulig- hed, at de er et udsat prekariat, uuddannede og uoplyste, white trash, eller hvad man nu ellers i sin fortvivlelse har søgt tilflugt til. Billedet er langt mere broget.

Der er tale om en støt vækst i det populistiske vælgerpotentiale siden 1980 . Fremgangen er sket i gode og onde tider, under såvel økonomiske kriser som under opsving. Den er sket på forskellige udviklingstrin i samfundets institutioner, og den har ikke ladet sig rokke af politisk med- eller modvind. Partiernes vækst er sket på trods af, ikke som følge af de strategier, andre partier har valgt for at bekæmpe populisterne.

Heinö ser ikke populismen som en alvorlig trussel mod demokratiet. I afmålte doser kan den have en positiv effekt eller rent ud betragtes som en vigtig del af demokratiet. Populisme er i dag en fast del af det eksisterende politiske landskab i Europa. Populismen fungerer som korrektiv til en politisk elite, der ikke respekterer de demokratiske spilleregler. Så vidt Heinö.

Men er et korrektiv det samme som et alternativ? Det mener Alternativ for Tyskland (AfD). Det populistiske parti, der ved to lejligheder har vundet mere end 20 pct. af stemmerne i tyske delstatsvalg, opfatter sig selv som et revolutionært parti, der hverken ligger til højre eller til venstre - ni droite, ni gauche, som anarkisternes kampråb engang lød. Her er korrektion ensbetydende med omvæltning.

AfD vil omstyrte det nuværende partistyrede tyske demokrati og erstatte det af et eksklusivt folkestyre efter identitetsprincipper, som kan udtrykkes med det belastede tyske ord 'völkisch'. Så sent som i september foreslog Frauke Petry, den ene af AfD's to ledere, at tyskerne rehabiliterer ordet, som i parentes bemærket under ingen omstændigheder må forveksles med det dan- 
De etablerede politikere er begyndt at ryste på hænderne. Polerne nærmer sig hinanden: Stadig flere etablerede partier kidnapper populisternes politik og dagsorden, mens højre- og venstrepopulister på deres side har lært at dæmpe deres officielle retorik, så den falder inden for det alment acceptable uden at give køb på bevægelsernes radikale krav.

ske ord folkelig. Völkisch betyder folkelig i etnisk, nationalistisk forstand og udgjorde selve kernen i den nazistiske herrefolksideologi. For nazisterne var nationen den ultimative dommer over sin egen adfærd. Den er sin egen verden, og den er hævet over internationale domstole og humanitære traktater.

\section{Kommet for at blive}

Cas Mudde, Europas i dag førende akademiske autoritet i spørgsmålet 'populisme', spørger i sit nyeste samleværk om populisme (On Extremism and Democracy in Europe, 2016): "Er kernen i det populistiske radikale højres politik - bestemt som en blanding af identitetspolitik, autoritetsdyrkelse og populisme - i strid med basale værdier i de vestlige samfund?

Og repræsenteres disse værdier kun af et mindretal?" Med forbehold er Muddes svar identisk med Heinös, nemlig i begge tilfælde: Nej.

Men interessant er det, at den hollandske statskundskabsforsker i bogens dramatisk formulerede efterord, skrevet umiddelbart efter terrorangrebene i Paris i november 2015, indrømmer sig selv retten til at være pessimist.

Efter Muddes mening overreagerede den franske socialistiske regering ved at indføre en undtagelsestilstand, der kun kunne bekræfte populistiske partier i Frankrig og andre steder i Europa i deres politiske overbevisninger. Populisternes fremgang blev væsentligt styrket i 2015, hvor EU blev konfronteret med en huma- nitær udfordring i form af et eksplosivt voksende antal flygtninge fra borgerkrigen i Syrien.

De etablerede politikere er begyndt at ryste på hænderne. Polerne nærmer sig hinanden: Stadig flere etablerede partier kidnapper populisternes politik og dagsorden, mens højre- og venstrepopulister på deres side har lært at dæmpe deres officielle retorik, så den falder inden for det alment acceptable uden at give køb på bevægelsernes radikale krav. Populister lærer også af deres erfaringer.

\section{Marine Le Pen}

I en stor analyse af det europæiske ekstreme højres politik og i særlig grad af Marine Le Pens smidige, ideologiske moderniseringer (Les droites extremes en Europe, 2015) skriver forfatterne Jean-Yves Camus og Nicolas Lebourg, at den franske Front National-leder har taget ved lære af sin far, den iltre og kompromisløse Jean-Marie Le Pens marginalisering i fransk politik. Men omvendt har hun søgt inspiration hos Gianfranco Fini, den italienske toppolitiker.

Fini begyndte som leder af et postfascistisk parti, MSI, men endte med kors og bånd og stjerner på som minister under Berlusconi og parlamentsformand. Siden har Fini hævdet sig som en alment agtet centrumpolitiker og Berlusconi-kritiker.

Så langt går Marine Le Pen næppe, men hamskiftet har for længst fundet sted. Hun har rømmet stort set alle de forposter, hendes far forsvarede. Hun har sagt 
farvel til antisemitisme, antizionisme og højrekatolicisme og meldt sig som behersket tilhænger af kvinders og selv homoseksuelles rettigheder - i en demonstrativ bestræbelse på at overlade denne scene til muslimer.

Alt har hun givet i bytte for den politik, der virkelig er stemmer $i$, nemlig kampen mod islam, mod 'de fremmede' (læs: muslimer) og mod immigration.

I den til dato mest dybdeborende analyse af Marine Le Pens retorik viser den fransk-amerikanske forsker Cécile Alduy imidlertid, at der for det meste er tale om en ændring i stil, ikke i indhold (Marine Le Pen prise au mots, 2015). Le Pen vil med sin alibistrategi erobre det kulturelle overherredømme i Frankrig og dernæst præsidentposten. Hun vil "normalisere Front Nationals retorik uden at tabe partiets radikalitet", skriver Alduy.

Alduys analyse af en endeløs række af Marine Le Pen-taler viser, at Front National-lederen henter næsten hele sin politik fra sin far, partiets stifter. Men hun rangerer den ind på en andenplads i forhold til nye og mere indbydende hovedtemaer. Hun forskønner faderens ubeherskede sprog og giver sine modstanderes synspunkter lige den drejning i betydning, der får dem til at ligne hendes egne til forveksling. Hun optræder som venligheden selv, i modsætning til faderen, som hun endog har ekskluderet af hans eget parti. Sproglige finesser: Marine Le Pen erstatter det kontroversielle ord 'nation' med plusordet 'folk'. Det mere neutrale ord 'immigrant' erstattes af det oplagt negative 'fremmed'. De værdier, hun forsvarer, når hun med beklagelse må sige nej til fremmede, er udelukkende samfundsøkonomiske. Derved imødegår hun humanistiske indvendinger og anklager for racisme.
I modsætning til sin far har Marine Le Pen heller intet at indvende imod jøder. Det, hun vender sig imod, er 'pengemagt', 'overnational kapitalisme, 'finansverdenens og bankernes diktatur,' 'ågerkarle,' 'spekulanter, der har bemægtiget sig verden' og en 'globaliseret klike af rige, der har sat sig på klodens rigdomme’.

Hvem hun lige præcis har i tankerne med disse betegnelser, må vi gætte os til.

Marine Le Pen kan være rolig. Hendes far har i 30 år lagt grunden. Hendes vælgere ved, hvad hun taler om, når hun bruger andre ord for det, de kender så udmærket i forvejen. De er taknemmelige for at blive iført et pænt jakkesæt uden fortidens pletter. Tankegangen er næsten som før, men ordene krænker ikke længere følsomheden og forekommer normale, ja rent ud saglige. Hun er stadig systemkritisk, men moralsk acceptabel.

\section{Vi er folket}

Hollænderen Cas Mudde advarer dem, der analyserer populismefænomenet, mod to farer: Den ene består i fristelsen til at søge forklaringsmodeller i mellemkrigstidens fascistiske, nazistiske og kommunistiske partier og ideologier. Brede populistiske partier reagerer på nutidens problemer og holder fingrene fra datidens racistiske eller klassebestemte terminologi. Det er en taberstrategi.

Den anden fare består i at psykologisere populismen. Mudde citerer den klassiske amerikanske sociolog Daniel Bell, der i 1964 sagde: "Det radikale højres politik er en frustrationens politik - en sur afmagt hos dem, der føler sig ude af stand til at forstå og endnu mindre styre det komplekse massesamfund, der udgør dagens politiske univers".

Denne tanke har fået mange til at ind- 
skrive radikale højre- og venstrebevægelser i massepsykologiske begrebsrammer. Populisme er i denne forstand en sindslidelse, en anomali, en forestillingsverden, der ligger uden for det normale politiske univers. Hvis det er tilfældet, er der tale om 'en patologisk normalitet', siger Mudde ironisk. Så kan vi tygge på den.

Men hans advarsler, der delvis ligger i forlængelse af Laclaus, fritager hverken ham eller Laclau for at tage stilling til populismen som en politisk bevægelse, hvis mål klart udfordrer vores opfattelse af, hvad der er basalt i et moderne europæisk folkestyre, nemlig ønsket om retfærdighed. Først det vestlige Europa og efter Murens fald også det østlige er blevet til i det, den italienske filosof Norberto Bobbio kalder 'l'età dei diritti', altså 'rettighedernes tidsalder', hvis fundament er de universelle menneskerettigheder, som FN vedtog i december 1948.

I frie, demokratiske samfund har denne erklæring været rettighedsskabende, den har skabt ret. Den har opmuntret os til at betragte demokrati som den politiske form for retfærdighed. I en global sammenhæng stiller erklæringen krav til alle regimer om at retfærdiggøre sig. Alt for mange undslår sig, men 28 stater i Europa har dannet en union for at fremme denne tanke om at lægge overnational ret til grund for deres samarbejde. Kun ét land agter foreløbig at forlade den.

Det samme krav om retfærdiggørelse må rejses over for populistiske bevægelser. Vores demokratier er retssamfund. Individet står i centrum, vi er statsborgere, medier og domstole er uafhængige, mindretal beskyttes. Vores værdier hviler på en sokkel af universalisme, trosfrihed, lighed, parlamentarisme, menneskerettigheder, fordømmelse af racisme. Den hori- sont kan ikke passeres ustraffet. Anfægtes nogle af disse rettigheder, må det begrundes. Vilkårlighed og diskrimination kan ikke længere accepteres.

\section{Når politiske bevægelser i demokratier hævder, at 'vi er folket', hviler påstanden på en urovækkende mangel på situationsfornemmelse. I et demokrati optræder folket altid i flertal. Ellers er det intet demokrati.}

Den prøve i retfærdiggørelse består de færreste populistiske partier i Europa.

Populisme kommer, som navnet siger, af populus, det latinske ord for folk. Hos højrepopulister udlægges begrebet 'folket' $i$ en etnisk version. 'Folket' bestemmes efter et afstamningsprincip (indfødsret på dansk) og en bestemt kultur eller tro. Ordet civilisation, der er snævert forbundet med borgerrettigheder, hører ikke hjemme i denne forestillingsverden, hvor identitet erstatter individualitet. Venstrepopulister forstår på deres side det statskonstituerende folk som en bestemt samfundsklasse, der har fortrin for andre.

I begge tilfælde må forestillingen om lighed vige for ønsket om eksklusion. Man anskuer samfundet dualistisk: Indenfor og udenfor. Modsætningerne mellem disse to skel er principielt uoverstigelige. Populistiske partier er anti-pluralistiske og dermed i åben modstrid med de forestillinger, der hidtil har hersket i vores demokratier.

I højrepopulisternes verdenssyn skal hvert 'folk' have lov til at udvikle sin egen 'identitet' uforstyrret af andre og på de egne af jorden, hvor de nu måtte høre hjemme. Tanken er, at mennesker frit må kunne udvikle deres egen kultur og iden- 
titet i ly for 'fremmede.' Jo mere ensartet en 'kultur' er, jo mere den får mulighed for at besinde sig på sine egne rødder og udtryk, jo bedre sidder dette folks 'identitet' fast - og et folk i sin identitet. Går man den modsatte vej, truer en 'Volkstod', som det udtrykkes på tysk: At et helt folk begår selvmord eller uddør. Tyskland afskaffer sig selv.

I dag taler ingen om racer. De europæiske autoritære og højrevendte populistiske partier taler i stedet om 'etnopluralisme', en tankegang, der som sådan er fast forankret i såvel AfD i Tyskland som i Marine Le Pens Front National i Frankrig. Diskussionen om flygtninge i særdeleshed og islam i almindelighed viser, at tanken er grundlæggende for den nationalistiske forestillingsverden i Europa i dag. I Sydafrika hed det apartheid, indtil denne raceadskillelse blev endeligt afskaffet i 1990'erne. Det skete i øvrigt samtidig med, at klassediktaturerne blev afskaffet i Østeuropa.
Til denne forestilling om 'folket' som en nations sande magthaver hører også forestillinger om, hvem der retmæssigt og med størst autoritet kan lede nationen. Højrepopulistiske partier ved regeringsmagten i Ungarn og Polen viser vej til et samfund, hvor stadig mere autoritære ledere gradvist ophæver demokratiske retsgarantier.

Folkeafstemninger, altså det direkte demokrati, der står på alle højrepopulistiske partiers program, er det ultimative udtryk for 'folkeviljen': Her fejes hensyn til mindretal og kompromisser til side, ja overhovedet forestillingen om politik. Resultatet af en folkeafstemning ligger enevælden nærmere end demokratiet.

Når politiske bevægelser i demokratier hævder, at 'vi er folket', hviler påstanden på en urovækkende mangel på situationsfornemmelse. I et demokrati optræder folket altid i flertal. Ellers er det intet demokrati. 